\title{
Predicting the probability of seed germination in Pinus sylvestris L. and four competitor shrub species after fire
}

\author{
$\mathrm{M}^{\mathrm{a}}$ Rosario Nuñez ${ }^{\mathrm{a}}$, Felipe Bravo ${ }^{\mathrm{a}}$ and Leonor Calvo ${ }^{\mathrm{b} *}$ \\ ${ }^{a}$ Departamento de Producción Vegetal y Silvopascicultura, E.T.S. de Ingenierías Agrarias, Universidad de Valladolid, Avda. de Madrid, $\mathrm{n}^{\circ}$ 57, \\ 34004 Palencia, Spain \\ b Área de Ecología, Facultad de Ciencias Biológicas y Ambientales, Universidad de León, 24071 León, Spain
}

(Received 8 April 2002; accepted 4 June 2002)

\begin{abstract}
Knowledge of the regeneration of competing shrub species after wildfire in Scots pine stands is essential for the regeneration of this tree species. The germination capability of seeds is modified by the temperature reached during a fire and the length of time that seeds are subjected to high temperatures. The probability of germination was studied in the laboratory for Scots pine (Pinus sylvestris) and four shrub species characteristic of the understory in Scots pine stands in northern Spain (Cistus laurifolius, Halimium umbellatum, Halimium alyssoides and Genista florida). Germination probability was studied with a logistic model that uses duration of exposure to the fire, the temperature and the interaction of both as independent variables. Results show a higher germination rate in shrub species at high temperature than for Scots pine. Thus by limiting competition between Scots pine and understory species, using prescribed burning or mechanical site preparation, Scots pine can regenerate successfully and quickly. This model can aid management decisions in this area.
\end{abstract}

germination / scots pine / shrub species / thermal shock

Résumé - Prédiction des probabilités de germination après le feu de Pinus sylvestris L. et de quatre espèces de garrigue. La régénération des espèces de garrigue après le feu est un facteur déterminant pour la réinstallation de Pinus sylvestris. La température pendant l'incendie et la durée de l'exposition modifient la capacité de germination des graines. Nous avons étudié au laboratoire la germination de Pinus sylvestris et de quatre espèces de garrigue (Cistus laurifolius, Halimium umbellatum, Halimium alyssoides et Genista Florida) qui sont typiques des forêts dominées par Pinus sylvestris. Afin de définir les probabilités de germination, on a utilisé la durée de l'exposition, la température et son interaction comme variables indépendantes, dans un modèle logistique. Les résultés de la germination suggèrent que les graines des espèces de garrigue présentent une meilleure germination après exposition à des hautes températures que les graines de Pinus sylvestris. En conséquence, les feux prescrits ou les entretiens mécaniques peuvent provoquer une régénération plus rapide et plus satisfaisante de Pinus sylvestris.

dynamique de germination / Pinus sylvestris / espèces du maquis / feu de forêt

\section{INTRODUCTION}

Scots pine (Pinus sylvestris L.) is one of the most important forest species across Europe from the boreal region in northern and eastern areas to the Mediterranean mountains in the southern part of the continent. An accurate assessment of the regeneration process of these stands is a key concept for sustainable management. This is true especially in the limits of its distribution in the Mediterranean basin. At present, forest fires are the most important cause of damage to the natural environment in the Mediterranean basin [51]. Amongst the countries of the Mediterranean basin, Spain is one of those with a relatively high fire risk and severity of burning [50]. Within Spain, León is the province with the largest wooded surface area burned in the last few years. Forty per cent of this area is cov- ered by coniferous species, mainly Pinus sylvestris and Pinus nigra, and the remaining 60\% by Quercus species (Del Hierro, personal communication).

Different factors must be considered in the post-fire succession. For example, vegetation characteristics before fire, fire temperature and fire intensity, ash concentration, nutrient balance, soil and air temperature, animal population associated to forest ecosystem, etc. All these factors together determine the vegetation response after forest fire [1, 25, 27].

The effects of fire on vegetation are usually the most obvious impact of burning. Fire affects natural ecosystems by consuming plants, altering successional patterns and changing vegetative resources such forage, wildlife habitats, etc. Understanding how fire affects vegetation is often a key to holistic, ecosystem-based, natural resource management [12]. 
Natural regeneration in Scots pine (Pinus sylvestris L.) stands has been well studied in boreal and Atlantic areas. Regeneration processes in these ecosystems have also been widely studied in the Mediterranean environment [6-8, 17, 18, $37,38,40,42]$ where fire is an important ecological factor. Interspecific competition is considered one of the key parameters in the regeneration process of tree species but natural regeneration can be affected by community composition. González Martínez and Bravo [19] found that the regeneration density of Scots pine stands is negatively related to the cover of Ericaceae species and Quercus species in northern Spain. Differences in linear growth rates for Scots pine compared with exponential growth rates for the initial stages of oak species [35], cause a clear initial competitive disadvantage for pine regeneration. Other factors, such as the quantity of seeds produced, depredation by herbivores, allelopathic effects among species or damage by cattle, have been suggested as explanatory variables for the same process $[2,19,23]$. Similarly, modifying the germination capacity of different species competing in a specific area may be one of the most significant factors affecting the competitive potential of the species involved. In the case of regeneration after a forest fire, the factors most likely to alter the germinative capacity are the temperature reached by the fire and its duration. Scots pine is an obligated seeder that does not show allelopathic effects as it occurs in other conifer species. Other coniferous species have been found capable of producing allelopathic substances, as occurs in the case of Pinus halepensis, which emits a considerable amount of terpenes [29], Picea abies, which emits phenol compounds from the green acicules to the soil solutions [16] and Pinus pinaster, which presents different amounts of terpenes and resinous acids in its acicules and bark [15]. These compounds act as powerful agents, which inhibit the germination and the growth of some herbaceous species when found in the substratum [25].

Previously, Escudero et al. [14] studied the germination probability of Spanish pines. In the field, regeneration involves different processes, including interspecific competition, but no study has modeled the behaviour of a pine species and its potential competitor in order to assist management actions. For this reason, this study is devoted to analysing the germination pattern of Scots pine and four potential competitors following thermal treatment. Finally, conclusions allow the development of management strategies to help regenerate Scots pine stands in northern Spain.

\section{MATERIALS AND METHODS}

The biological materials used in this study were seeds of Pinus sylvestris, Halimium umbellatum, Halimium alyssoides, Genista florida and Cistus laurifolius.

Two species that can be considered as colonisers are Halimium alyssoides and Halimium umbellatum. These species used germination as a regeneration mechanism and both of them take advantage of the empty spaces to germinate and increase cover as well as the space they occupy [7]. The beneficial effects of thermal shock on the seeds of these species have been widely studied [36]. However, in this study, cutting and ploughing also had a significant positive effect on the germination of these species. Therefore perturbations that create open spaces favour both species.
Genista florida is a legume that uses both seeds and sprouting to regenerate, but after fire the germination is promoted [37]. Finally, Cistus laurifolius proliferating appreciably in some burnt areas, are among those considered as heliophylous that colonize the altered areas, free of aggressive competitors [42]. Cistus laurifolius reproduce actively after fire but only via seeds.

The seeds of Pinus sylvestris were obtained from the Dirección General de Conservación de la Naturaleza, Ministerio de Medio Ambiente (1994-1995 harvest); the source region used was the "Montaña soriano-burgalesa", northern Spain. The seeds of the shrub species were obtained from shrub formations that represent Scots pine undergrowth in northern Spain (León Province and Palencia province). After eliminating damaged seeds, the remainders were stored in open paper bags, which permitted ventilation, in a dry place at laboratory temperature until they were used. In order to discover the effect of fire on germination, a method widely used by various authors [37, 44] was employed. This method consists of exposing seeds to high temperatures for short periods of time in order to simulate the action of fire under conditions, which are as natural as possible. According to Trabaud [41], the heat of a fire operates on a concrete point for only a short period of time (between 5 and $15 \mathrm{~min}$ ) and the temperatures reached at $2.5 \mathrm{~cm}$ below the soil surface varies between 44 and $150^{\circ} \mathrm{C}$. Pinus sylvestris seeds were subjected to different thermal shocks: $70{ }^{\circ} \mathrm{C}, 90^{\circ} \mathrm{C}, 110^{\circ} \mathrm{C}, 130^{\circ} \mathrm{C}, 150{ }^{\circ} \mathrm{C}, 170{ }^{\circ} \mathrm{C}$, $190{ }^{\circ} \mathrm{C}$ for 1 and 5 minutes and control treatment (no thermal treatment). In accordance with others authors the shrub seeds were subjected to the following treatments: $50^{\circ} \mathrm{C}, 75^{\circ} \mathrm{C}, 100{ }^{\circ} \mathrm{C}$ and $125^{\circ} \mathrm{C}$ for $1,5,10$ and 15 minutes and a control treatment. The control was included in the data analysis as $20^{\circ} \mathrm{C}$ and one minute following Escudero et al. [14]. As we use a modeling approach (see below), the use of different temperature and time exposure values for each species doesn't matter.

Immediately after treatments the seeds were sown in $8.5 \mathrm{~cm}$ diameter Petri dishes on four layers of filter paper saturated with demineralised water. There were 5 replicates of 20 seeds for each treatment. These treatments were compared with another group of 5 replicates, which were not subjected to thermal shock. The dishes were placed in a controlled environment cabinet at a temperature of $20^{\circ} \mathrm{C} \pm 1{ }^{\circ} \mathrm{C}$ with photoperiods of 15 hours light/9 hours dark, according with other experimental studies involving this species (Torres et al., unpublished data). A temperature of $20^{\circ} \mathrm{C}$ was used, like in other germination studies where temperatures used varied between $20^{\circ} \mathrm{C}$ and $23^{\circ} \mathrm{C}$ [45]. The number of germinating seeds was counted every week for 6 weeks. A seed was considered to have germinated when the radicle could be seen with the naked eye [9].

Logistic regression [30] was used to determine whether the explanatory variables allowed germination probability after thermal treatment to be predicted. Logistic regression is a straightforward method of analysing processes such as death, survival or germination and has been used previously in forest ecology $[5,14]$. The exposure time to the thermal treatment and the temperature at which the seeds were subjected were used as explanatory variables. The full model (temperature, time and their interaction), including independent terms, and all reduced models were tested. The logistic model is expressed as:

$$
p=\frac{1}{1+e^{-\mathrm{z}}}
$$

where $\mathrm{p}$ is the germination probability and $\mathrm{z}$ a linear function which contains the explanatory variables considered $\left(Z=a_{0} \times\right.$ temperature $+\mathrm{a}_{1} \times$ time $+\mathrm{a}_{2} \times$ temperature $\times$ time). The coefficients of the $\mathrm{z}$ function are obtained using maximum likelihood function. The models were selected using the change in the value of $-2 \log$ likelihood between the model with and without explanatory variables [22]. Plant nomenclature follows Tutin et al. [47]. 
Table I. Percentage of germination of Pinus sylvestris and four shrub species after different thermal chocks and control situation.

\begin{tabular}{|c|c|c|c|c|c|c|c|c|c|c|c|c|c|c|c|c|c|}
\hline & \multirow[t]{2}{*}{ Control } & \multicolumn{4}{|c|}{$50^{\circ} \mathrm{C}$} & \multicolumn{4}{|c|}{$75^{\circ} \mathrm{C}$} & \multicolumn{4}{|c|}{$100^{\circ} \mathrm{C}$} & \multicolumn{4}{|c|}{$125^{\circ} \mathrm{C}$} \\
\hline & & $1 \mathrm{~min}$ & $5 \mathrm{~min}$ & $10 \mathrm{~min}$ & $15 \mathrm{~min}$ & $1 \mathrm{~min}$ & $5 \mathrm{~min}$ & $10 \mathrm{~min}$ & $15 \mathrm{~min}$ & $1 \mathrm{~min}$ & $5 \mathrm{~min}$ & $10 \mathrm{~min}$ & $15 \mathrm{~min}$ & $1 \mathrm{~min}$ & $5 \mathrm{~min}$ & $10 \mathrm{~min}$ & $15 \mathrm{~min}$ \\
\hline Halimium alyssoides & 4 & 0 & 2 & 1 & 4 & 2 & 6 & 1 & 2 & 4 & 28 & 44 & 62 & 7 & 52 & 54 & 7 \\
\hline Halimium umbellatum & 16 & 4 & 7 & 2 & 3 & 7 & 4 & 8 & 14 & 3 & 12 & 12 & 32 & 48 & 6 & 1 & 0 \\
\hline Cistus laurifolius & 68 & 52 & 61 & 56 & 43 & 56 & 59 & 36 & 49 & 52 & 44 & 54 & 66 & 56 & 60 & 54 & 1 \\
\hline \multirow[t]{3}{*}{ Genista florida } & 23 & 12 & 17 & 18 & 20 & 21 & 31 & 23 & 20 & 22 & 46 & 30 & 43 & 42 & 28 & 13 & 2 \\
\hline & Control & & ${ }^{\circ} \mathrm{C}$ & 90 & ${ }^{\circ} \mathrm{C}$ & 110 & ${ }^{\circ} \mathrm{C}$ & 130 & ${ }^{\circ} \mathrm{C}$ & & $0^{\circ} \mathrm{C}$ & & $0{ }^{\circ} \mathrm{C}$ & & $0^{\circ} \mathrm{C}$ & & \\
\hline & & $1 \mathrm{~min}$ & $5 \mathrm{~min}$ & $1 \mathrm{~min}$ & $5 \mathrm{~min}$ & $1 \mathrm{~min}$ & $5 \mathrm{~min}$ & $1 \mathrm{~min}$ & $5 \mathrm{~min}$ & $1 \mathrm{~min}$ & $5 \mathrm{~min}$ & $1 \mathrm{~min}$ & $5 \mathrm{~min}$ & $1 \mathrm{~min}$ & $5 \mathrm{~min}$ & & \\
\hline Pinus sylvestris & 94 & 94 & 95 & 93 & 90 & 92 & 8 & 78 & 0 & 27 & 0 & 0 & 0 & 0 & 0 & & \\
\hline
\end{tabular}

\section{RESULTS}

Germination results of Scots pine and the four undergrowth species (table I) indicate that the four obligatory seeder species (Pinus sylvestris, Cistus laurifolius, Halimium alyssoides and $H$. umbellatum) behave differently under thermal treatment.

Results from the control situation are similar to previous works [48, 49]. The only exception is Halimium alyssoides, which show germination rates low in the control situation.

Scots pine reached its maximum germination rates at relatively low temperatures $\left(70^{\circ} \mathrm{C}-90^{\circ} \mathrm{C}\right)$ and without significant differences from control treatment. Germination rates decrease significantly at temperatures higher than $110^{\circ} \mathrm{C}$ and an exposure time of five minutes. Cistus laurifolius shows relatively high germination rates, similar to the control, up to $125^{\circ} \mathrm{C}$ and an exposure time of 15 minutes. So, this species possesses a high resistance against high temperatures. The two Halimium species analysed show completely different behaviour to that of Scost pine because they exhibit maximum germination rates at high temperatures (between 100 and $125^{\circ} \mathrm{C}$ ) and long exposure time, but their embryos were killed at $125^{\circ} \mathrm{C}$ for $15 \mathrm{~min}$. In our study Genista florida (simultaneously a sprouter and seeder species) show good germination rates at high temperatures.

From laboratory results, different logistic models for Pinus sylvestris, Cistus laurifolius, Halimium umbellatum, Halimium alyssoides and Genista florida were tested using the germination results after thermal shock. The value of $-2 \log$ likelihood and the variable significance were used for this. Different models were selected for each species (table II). Using the fitted models, the germination probability of the five species studied was calculated for different conditions (figure 1). It is important to note that in some cases the model is used out of the original data set range. The results obtained show that Pinus sylvestris has the greatest germination probability with low exposure temperatures (up to $100^{\circ} \mathrm{C}$ ). As the exposure time increases, the species resists these temperatures less. Thus, with an exposure time of 1 minute, the probability of germination decreases significantly above $120^{\circ} \mathrm{C}$. With an exposure time of 5 minutes this decrease occurs at $100{ }^{\circ} \mathrm{C}$; and with times of 10 and 15 minutes harmful temperatures are lower. In the thermal treatments that allow maximum germination probabilities to be obtained, there are no differences in germination probability between these and the control situation $\left(20^{\circ} \mathrm{C}\right)$.
Cistus laurifolius exhibits special behaviour, as it has the same germination probability in both the control situation and at the different temperatures, although this probability decreases slightly when the exposure times increase. In the case of Genista florida and Halimium umbellatum (figure 1) the germination probabilities remain practically constant throughout the thermal range with exposure times of 1 and 5 minutes. However, with exposure times of 10 and 15 minutes a clear decrease in germination is observed when the temperature increases. Thus, at temperatures above $160{ }^{\circ} \mathrm{C}$, the germination probability is below $1 \%$. The behaviour of Halimium alyssoides (figure 1) contrasts with the previous two species.

In general, the model predicts that for all shrub species, the temperature required for a higher germination probability than Pinus sylvestris, decreases as exposure time increases.

All fitted models contain exposure time as an explanatory variable (tables II and III). In the case of the seeds of Pinus sylvestris and Halimium alyssoides, temperature is also significant. Finally, the interaction between the time and the temperature was only significant in the cases of Pinus sylvestris, Halimium umbellatum and Genista florida. The correct classification percentage, using the selected models, varies between more than $95 \%$ in the case of Scots pine and $43 \%$ in the case of Cistus laurifolius. Table III shows the coefficients of the selected models

\section{DISCUSSION}

Competition between tree, shrub and herb species for resources like water can limit the success of arboreal regeneration in a forest ecosystem after fire $[11,19]$. This is especially important in areas with sandy soils where edaphic water retention is low. Bravo and Montero [4] established that the sandy soil in pine stands in northern Spain are areas of low productivity. However, González Martínez and Bravo [18] state that there is no relationship between height growth and site productivity in young Scots pine stands in northern Spain. It is well known in practical forestry in Spain that the presence of Genista florida [28, 33, 34] and other competitor species such as hardwoods or Ericaceae [18] are associated with problems in the regeneration of Scots pine stands. In these cases, limiting competition between species may favour pine stand regeneration. A possible method to achieving this could be prescribed burning to limit interspecies competition. It is well established that the fire regime has important implications for 
Table II. Main characteristics of the logistic models fitted for the species studied.

\begin{tabular}{|c|c|c|c|c|}
\hline Species & Model & $\begin{array}{l}-2 \log \mathrm{L} \\
\text { (constant) }\end{array}$ & $\begin{array}{c}-2 \log \mathrm{L} \\
\text { (model) }\end{array}$ & Correct classification (\%) \\
\hline \multirow[t]{4}{*}{ Pinus sylvestris } & $\mathrm{T}$ & 2062.768 & 1021.425 & 90.1 \\
\hline & $\mathrm{t}$ & & 1902.824 & 43.6 \\
\hline & $\mathrm{T}, \mathrm{t}$ & & 777.843 & 95.5 \\
\hline & $\mathrm{T}, \mathrm{t}, \mathrm{T}^{*} \mathrm{t}$ & & 699.807 & 95.8 \\
\hline \multirow[t]{5}{*}{ Halimium umbellatum } & $T$ & 1028.629 & 1026.154 & 42.7 \\
\hline & $\mathrm{T}$ & & 1011.364 & 47.6 \\
\hline & $T, \mathrm{t}$ & & 1006.268 & 56.7 \\
\hline & $T, \mathrm{t}, \mathrm{T}^{*} \mathrm{t}$ & & 988.884 & 54.9 \\
\hline & $\mathrm{T}, \mathrm{T}^{*} \mathrm{t}$ & & 993.147 & 54.7 \\
\hline \multirow[t]{4}{*}{ Halimium alyssoides } & $\mathrm{T}$ & 1419.749 & 1373.652 & 51.7 \\
\hline & $\mathrm{T}$ & & 1227.480 & 65.5 \\
\hline & $\mathrm{T}, \mathrm{t}$ & & 1193.687 & 77.3 \\
\hline & $\mathrm{T}, \mathrm{t}, T^{*} t$ & & 1192.349 & 77.4 \\
\hline \multirow[t]{5}{*}{ Genista florida } & $T$ & 1332.595 & 1331.653 & 41.0 \\
\hline & $t$ & & 1332.453 & 38.7 \\
\hline & $T, t$ & & 1331.368 & 47.8 \\
\hline & $T, \mathrm{t}, \mathrm{T}^{*} \mathrm{t}$ & & 1321.528 & 53.4 \\
\hline & $\mathrm{T}, \mathrm{T}^{*} \mathrm{t}$ & & 1324.394 & 51.8 \\
\hline \multirow[t]{5}{*}{ Cistus laurifolius } & $T$ & 2343.092 & 2337.852 & 41.8 \\
\hline & $\mathrm{T}$ & & 2325.600 & 43.0 \\
\hline & $\mathrm{t} \#$ & & 2327.073 & 43.0 \\
\hline & $T, \mathrm{t}$ & & 2322.092 & 53.2 \\
\hline & $T, t, T^{*} t$ & & 2316.731 & 52.5 \\
\hline
\end{tabular}

T: Temperature; t: time; \#: model without independent term; $-2 \log \mathrm{L}$ is the $-2 \log$ likelihood including only the constant of the complete model. The models in bold are the selected ones. The coefficients of the variables in italics are not significant using a probability level of 0.05 .

Table III. Coefficients of the selected logistic models.

\begin{tabular}{ccccc}
\hline Species & Independent term & $\mathrm{T}$ & $\mathrm{t}$ & $\mathrm{T} * \mathrm{t}$ \\
\hline Pinus sylvestris & 5.8138 & -0.0307 & 2.3153 & -0.0292 \\
Halimium umbellatum & -2.8443 & - & 0.1722 & -0.00129 \\
Halimium alyssoides & -4.8884 & 0.0150 & 0.1928 & - \\
Genista florida & -1.9149 & - & 0.0727 & -0.0008 \\
Cistus laurifolius & - & - & -0.0293 & - \\
\hline
\end{tabular}

T: Temperature; t: time. All parameters with $P>0.0001$.

plant community composition within ecosystems $[12,52]$. As indicated by Hanley [20], the growth responses of seeds that have been subjected to thermal treatment may provide some clues as to how fire-adapted regeneration strategies influence the patterns of recruitment observed in post-fire plant communities.

In these pine stand communities after burning, species with different recovery strategies appear: some are obligate seeders like Pinus sylvestris, Cistus laurifolius, Halimium alyssoides and Halimium umbellatum, others use vegetative sprouting, and finally there are those that can use both mechanisms, such as Genista florida. Species that can regenerate both by sprouting and seeding tend to reproduce by sprouting, since it allows them to quickly reoccupy the available space [26, 41].

In general, the germination of many of the obligate seeder species, as Cistus spp., Halimium spp. and Pinus spp., is stim- ulated by increased heat [31]. However, their germination does not depend exclusively on the thermal increase caused by fire [21, 42], as they also germinate under control conditions. The viability of seeds and the survival of seedlings in natural conditions are key factors for sexual regeneration of woody species [3]. In addition, the regeneration of Pinus depends on the presence or absence of seed sources in and near the burne sites.

The beneficial effect on germination produced by thermal shock in many of these species, such as the Cistaceae family: Halimium alyssoides, Halimium umbellatum and Cistus laurifolius, can be compared with that found by other authors in the Mediterranean area [10, 21, 36-40, 46, 48]. As Cistaceae species show a high germination rate after thermal shock, there is a high probability that these species produce a reduction in the 


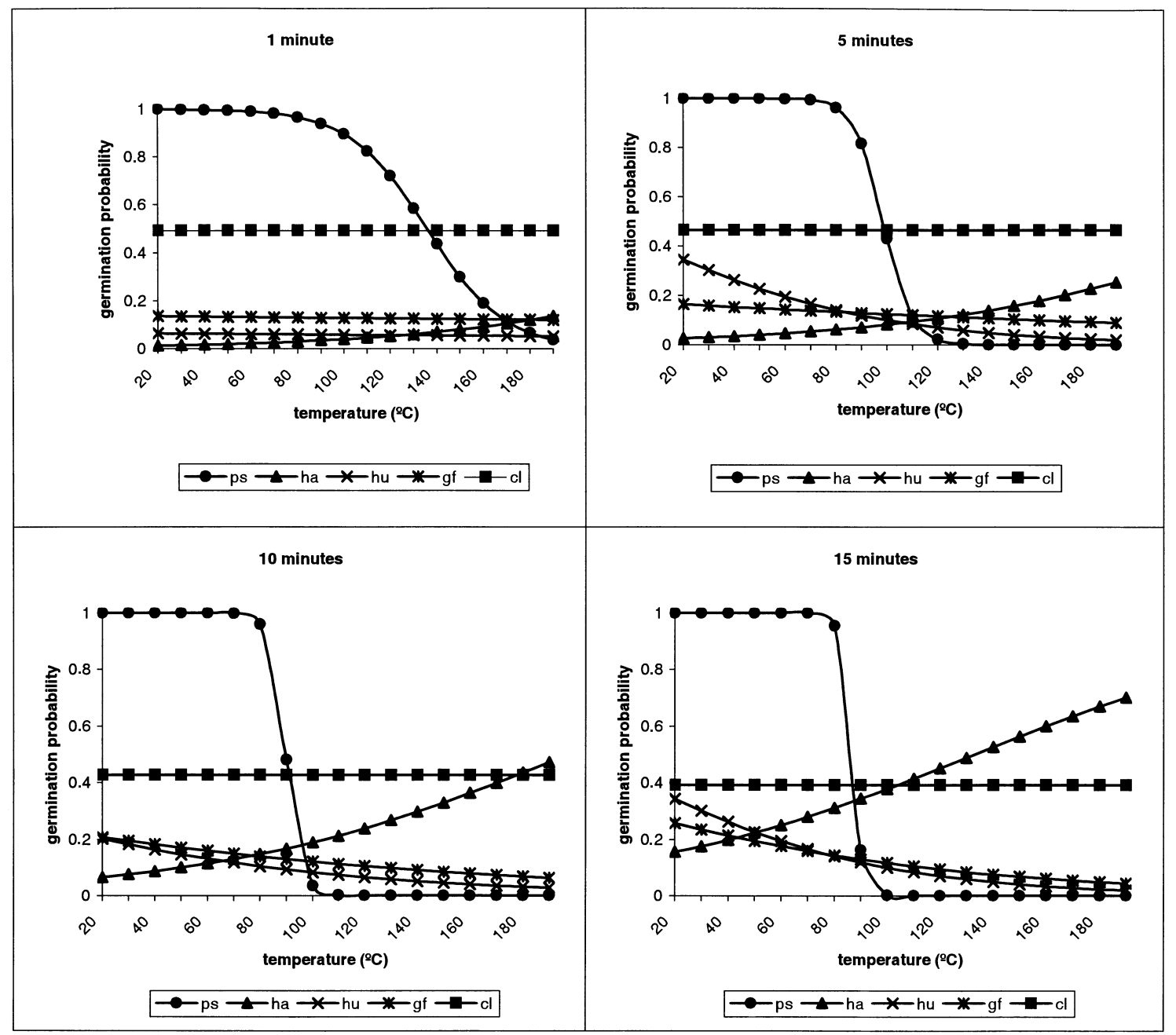

Figure 1. Germination probability of the species studied. It must be considered that in some temperature and time exposure combinations, the logistic models are used out of the original data set, so the graphs show extrapolations in some situations. ps: Pinus sylvestris; ha: Halimium alyssoides; hu: Halimium umbellatum; gf: Genista florida; and cl: Cistus laurifolius.

regeneration of trees in Scots pine stands. So as previously demonstrated by other authors works, vegetation-control treatment is highly recommended to improve Scots pine trees regeneration.

In the case of Pinus sylvestris, the germination probability in the control situation is similar to that found in thermal treatments up to approximately $90^{\circ} \mathrm{C}$. This probability is considerably reduced at higher temperatures and high exposure times. These results correspond with those reported by Escudero et al. [13] that show that temperatures above $70^{\circ} \mathrm{C}$ and an exposure time of 5 minutes are lethal to germination. Reyes and Casal $[31,32]$ found that the critical point must be located between $90^{\circ} \mathrm{C} / 1 \mathrm{~min}$ and $90^{\circ} \mathrm{C} / 5 \mathrm{~min}$. The behaviour of this species of Pinus allows us to suggest that it is not a pyrophyte but is probably an opportunist species that can germinate very well when strong competitors are not present. Similar results have been presented by Trabaud [43] in studies with Pinus halepensis. However, clear differences between Scots and Aleppo pines have also been observed [27].
Limited seedling recruitment in forest species due to interspecific competition is widely recorded elsewhere. It has been reported that shrub species affect Scots pine regeneration [19]. Although spatial heterogeneity [24] and an efficient dispersal strategy [14] have been suggested as possible explanations for height growth in Scots pine, interspecific competition can also explain the multicohort stand dynamic found in Scots pine stands [19].

Field data show than one year after a fire, the density of pine seedlings is less than 3 per square metre (unpublished data), while the cover of shrub species reaches over $50 \%$. So, it is clear than competition from shrubs can make natural regeneration of Scots pine difficult in northern Spain.

Therefore, in practical forestry limiting competition by prescribed burning or mechanical site preparation could favour successful and rapid Scots pine regeneration. An increase of 0.03 to 1.3 seedlings $\mathrm{m}^{-2}$ has been predicted when a site is prepared [19]. Prescribed burning can be used as a silvicultural alternative to improve regeneration practices, especially with 
temperatures under $90{ }^{\circ} \mathrm{C}$ and short exposure times to fire which give Scots pine the advantage over its shrub competitors. Due to social concerns about forest fires, the use of prescribed burning is limited in Spain. Each tree or shrub species responds differently to increased temperatures. An understanding of these differences allows possible management actions on these communities to be identified. It can be deduced from the results obtained (figure 1) that a prescribed fire moving at high speed (one minute residence time) has practically no effect on the germination probability of Scots pine seeds, so this species will benefit from this form of intervention. In contrast, a prescribed fire with a long residence time (10 minutes or longer) harms the germinative capacity of Scots pine seeds when the temperature exceeds $90{ }^{\circ} \mathrm{C}$, favouring the competitor shrub species. Núñez and Calvo [27] found that high temperatures did not benefit the germination of Pinus sylvestris. In contrast, Tárrega et al. [37] recorded that high temperatures favoured the germination of Genista florida. Therefore, a balance between the elimination of competitor shrub species and the stimulation of the germination of Pinus sylvestris seeds must be considered when prescribed burning is used to ensure the regeneration of Scots pine. In addition, other aspects, such as seed production, initial growth of seedlings, loss of nutrients after a fire or economic considerations, must be tackled before proposing the extension of prescribed fires as an alternative means of favouring the regeneration of Scots pine.

\section{REFERENCES}

[1] Ahlgren C.E., Some effects of fire on reproduction and growth of vegetation in northeastern Minnesota, Ecology 41 (1960) 431-444.

[2] Almqvist C., Bergsten U., Bondesson L., Eriksson U., Predicting germination capacity of Pinus sylvestris and Picea abies seeds using temperature data from weather stations, Can. J. For. Res. 28 (1998) 1530-1535.

[3] Bationo B.A., Ouedraog S.J., Guinko S., Longévité des graines et contraintes à la survie des plantules d'Afzelia africana Sm. dans une savane du Burkina Faso, Ann. For. Sci. 58 (2001) 69-75.

[4] Bravo F., Montero G., Site index estimation in Scots pine (Pinus sylvestris L.) stands in the High Ebro Basin (northern Spain) using soil attributes, Forestry 74 (2001b) 395-406.

[5] Bravo F., Hann D.W., Maguire D.A., Impact of competitor species composition on predicting diameter growth and survival rates of Douglas-fir trees in southwestern Oregon, Can. J. For. Res. 31 (2001a) 2237-2247.

[6] Calvo L., Tárrega R., Luis E., Regeneration in Quercus pyrenaica ecosystems after surface fires, Int. J. Wild. Fire 1 (1991) 205-210.

[7] Calvo L., Tárrega R., Luis E., Space-time distribution patterns of Erica australis L. subsp. aragonensis (Willk) after experimental burning, cutting, and ploughing, Plant Ecol. 137 (1998a) 1-12.

[8] Calvo L., Tárrega R., Luis E., Twelve years of vegetation changes after fire in an Erica australis community, in: Trabaud L. (Ed), Fire management and landscape ecology, International Association of Wildland Fire, Fairfield, Washington, 1998, pp. 123-136.

[9] Come D., Les obstacles à la germination, Masson, Paris, 1970.

[10] Corral R., Pita J.M., Pérez-García F., Some aspects of seed germination in four species of Cistus L., Seed Sci. Technol. 18 (1990) 321-325.

[11] Davis M.A., Wrage K.J., Reich P.B., Competition between tree seedling and herbaceous vegetation: support for a theory of resource supply and demand, J. Ecol. 86 (1998) 652-661.

[12] DeBano L.F., Neary D.G., Folliott P.F., Fire's effects on ecosystems, John Wiley \& Sons, Inc., New York, 1998.
[13] Escudero A., Barrero S., Pita J.M., Effects of high temperatures and ash on seed germination of two Iberian pines (Pinus nigra ssp. Salzmannii, Pinus sylvestris var iberica), Ann. Sci. For. 54 (1997) 553-562.

[14] Escudero A., Sanz M.V., Pita J.M., Pérez-García F., Probability of germination after heat treatment of native Spanish pines, Ann. For. Sci. 56 (1999) 511-520.

[15] Fernández De Simón B., García-Vallejo M.C., Cadahía E., Arrabal C., Cortijo M., Variación estacional de la composición terpénica de la acícula de Pinus pinaster Ait. III Congreso Forestal Español Tomo II, Granada, 2001, pp. 703-709.

[16] Gallet C., Pellissier F., Phenolic compounds in natural solutions of a coniferous forest, J. Chem. Ecol. 23 (1997) 2401-2412.

[17] González Martínez S.C., Bravo F., Regeneración natural, establecimiento y primer desarrollo del pino silvestre (Pinus sylvestris L.) Invest. Agr.: Sist. Recur. For.: Fuera de Serie $n^{\circ} 1$ (1999) 225-247.

[18] González Martínez S.C., Bravo F., Efecto de la calidad de estación en el crecimiento de la regeneración natural del pino silvestre (Pinus sylvestris L.) en el Alto Valle del Ebro (Burgos), Reunión de la SECF sobre Regeneración Natural, Lugo (Spain), 2000.

[19] González Martínez S.C., Bravo F., Density and population structure of the natural regeneration of Scots pine (Pinus sylvestris L.) in the High Ebro basin (northern Spain), Ann. For. Sci. 58 (2001) 277-288.

[20] Hanley E., Fenner M., Pre-germination temperature and the survivorship and onward growth of Mediterranean fire-following plant species, Acta Oecol. 19 (1998) 181-187.

[21] Herranz J.M., Ferrandis P., Martínez-Sánchez J.J., Influence of heat on seed germination of nine woody Cistaceae species, Int. J. Wild. Fire 9 (1999) 173-182.

[22] Hosmer D.W. Jr., Lemeshow S., Applied logistic regression, John Wiley and Sons, New York, 1999.

[23] Jäderlund A., Zackrisson O., Nilssön M.C., Effects of bilberry (Vaccinium myrtillus L.) litter on seed germination and early seedling growth of four boreal tree species, J. Chem. Ecol. 22 (1996) 973-986.

[24] Kuuluvainen T., Hokkanen T.J., Järvinen E., Pukkala T., Factors related to seedling growth in a boreal Scots pine stand: a spatial analysis of a vegetation-soil system, Can. J. For. Res. 23 (1993) 2101-2109.

[25] López Mosquera M.E., Guillén L., Primeros datos sobre el empleo de corteza de pino tratada para el control de malas hierbas, Actas del Congreso de la Sociedad Española de Malherbología (1993) 272-275.

[26] Naveh Z., The evolutionary significance of fire in the Mediterranean region, Vegetatio 29 (1975) 199-208.

[27] Nuñez M.R., Calvo L., Effect of high temperatures on seed germination of Pinus sylvestris and Pinus halepensis, For. Ecol. Manage. 131 (2000) 183-190.

[28] Morillo J.M., Estudio de las causas que limitan la regeneración natural de Pinus sylvestris L. en el cuartel D del monte Cabeza de Hierro. BSc thesis, EUITF-UPM, Madrid, 1987.

[29] Peñuelas J., Llusia J., Influence of intra- and inter-specific interference on terpene emission by Pinus halepensis and Quercus ilex seedlings, Biol. Plant. 41 (1998) 130-143.

[30] Ramsey F., Schaffer D., The statistical sleuth. A course in methods of data analysis, Duxbury Press, Belmont, CA, 1997.

[31] Reyes O., Casal M., Germination behaviour of 3 species of the genus Pinus in relation to high temperatures suffered during forest fires, Ann. Sci. For. 52 (1995) 385-392.

[32] Reyes O., Casal M., The influence of seed age on germinative response to the effects of fire in Pinus pinaster, Pinus radiata and Eucalyptus globulus, Ann. For. Sci. 58 (2001) 439-447.

[33] Rubio L.V., Estudio de las causas que limitan la regeneración natural de Pinus sylvestris L. en el cuartel B del monte Cabeza de Hierro. BSc thesis, EUITF-UPM, Madrid, 1987, 380 p. 
[34] Santos M., Estudio de las causas que limitan la regeneración natural de Pinus sylvestris L. en el cuartel E del monte Cabeza de Hierro. BSc thesis, EUITF-UPM, Madrid, 1987.

[35] Schepper (De) C., Typology of the natural regeneration in a middleaged Scots pine forest, Silva Gandavensis 53 (1988) 29-60.

[36] Thanos C.A., Georghiou K., Kadis C.C., Pantazi C., Cistaceae: A plant family with hard seeds, Isr. J. Bot. 41 (1992) 251-263.

[37] Tárrega R., Calvo L., Trabaud L., Effect of high temperatures on seed germination of two woody Leguminosae, Vegetatio 102 (1992) 139-147.

[38] Tárrega R., Luis E., Alonso I., Comparison of the regeneration after burning, cutting and ploughing in a Cistus ladanifer shrubland, Vegetatio 120 (1995) 56-67.

[39] Thanos G.A., Georghiou K., Ecophysiology of fire-stimulated seed germination in Cistus incanus subsp. creticus (L.) Heywood and C. salvifolius L., Plant Cell Environ. 11 (1988) 841-849.

[40] Thanos G.A., Marcou S., Christodoulakis P., Yannitsaros A., Early post-fire regeneration in Pinus brutia forest ecosystems of Samos island (Greece), Acta Oecol.-Oecol. Plant. 10 (1989) 79-94.

[41] Trabaud L., Dynamics after fire of sclerophyllous plant communities in the Mediterranean basin, Ecol. Medit. 13 (1987) 25-37.

[42] Trabaud L., Modalités de germination des cistes et des pins méditerranéens et colonisation des sites perturbés, Rev. Ecol. (Terre Vie) 50 (1995) 3-14.

[43] Trabaud L., Post-fire regeneration of Pinus halepensis forest in the west mediterranean, in: Neèman G., Trabaud L. (Eds.), Ecology, biogeography and management of Pinus halepensis and P. brutia forest ecosystems in the Mediterranean basin, Backhuys Publishers, 2000, pp. 257-268.

[44] Trabaud L., Casal M., Réponses des semences des Rosmarinus officinalis à différents traitments simulant une action de feu, Acta Oecol. 10 (1989) 355-363.

[45] Trabaud L., Oustric J., Heat requirements for seed germination of three Cistus species in the garrige of Southern France, Flora 183 (1989) 321-325.

[46] Trabaud L., Oustric J., Influence du feu sur la germination des semences de quatre espèces ligneuses méditeranéennes à reproduction sexuée obligatoire, Seed Sci. Technol. 17 (1989) 589-599.

[47] Tutin T.G., Heywood V.H., Burges N.A., Valentine D.H., Moore D.M., Walters S.M., Webb D.A., Flora Europea, Cambridge University Press, 1964-1980.

[48] Valbuena L., Tárrega R., Luis E., Influence of heat on seed germination of Cistus laurifolius and Cistus ladanifer, Int. J. Wild. Fire 2 (1992) 15-20.

[49] Valbuena L., El banco de semillas del suelo y su papel en la recuperación de comunidades incendiadas, Thesis Doctoral, Univ. León, 1995

[50] Vélez R., Los incendios forestales en España, Ecología, Fuera de serie 1 (1990) 213-221.

[51] Vélez R., La defensa contra incendios forestales. Fundamentos y experiencias, McGraw Hill, Madrid, 2000.

[52] Williams J.E., Whelan R.J., Gill A.M., Fire and environmental heterogeneity in southern temperate forest ecosystems: Implications for management, Aust. J. Bot. 42 (1994) 125-137. 